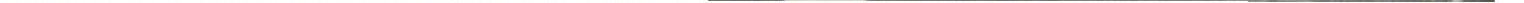




\section{Professor Dr. Mário Masagão}

(Catedrático de Direito Administrativo e Ciência da Administração.)

Filho de Thiago Masagão e D. Cândida do Amaral Carvalho Masagão, nasceu em São Carlos, dêste Eistado, a 9 de Outubro de 1899.

Bacharelou-se em Ciências Jurídicas e Sociais, pela Faculdade de Direito de São Paulo, en 1919, passando a exercer a advocacia.

Em Setembro de 1927, inscreveu-se em concurso para docência livre de Direito Administrativo e Ciência da Administração, na mesma Faculdade. Realizado em Outubro de 1928 aquêle concurso, foi unânimemente aprovado, con grau 10, e nomeado docente livre por portaria de 14 de Novembro, assumindo o exercício do cargo a 16 do mesmo mês.

Foi logo depois encarregado da regência da cadeira, em substituição ao Professor Catedrático, Dr. Manoel Pedro Villaboim, substituição que exerceu durante cinco anos consecutivos.

Em 1931 regeu também a cadeira de Economia Política e Ciências das Finanças, em substituição, no $20^{\circ}$ ano do curso, do respectivo Professor Catedrático, Dr. J. J. Cardoso de Melo Neto.

Por decreto de 12 de Dezembro de 1930, foi nomeado Ministro do Tribunal de Justiça do Estado, com assento na Quarta Câmara do mesmo Tribunal.

Em 1933 inscreveu-se em concurso para provimento da vaga de professor catedrático de Direito Administrativo, ocorrida com a aposentadoria do Dr. Manoel Pedro Vilaboim. Unânimemente aprovado, de novo com grau 10, foi 
nomeado professor catedrático daquela disciplina, por decreto de 25 de Setembro de 1933.

De 22 de Agôsto a 15 de Dezembro de 1933, exerceu o cargo de Secretário da Justiça e da Segurança Pública do Estado, no início do govêrno do Interventor Dr. Armando de Sales Oliveira.

A 4 de Outubro de 1933, em sessão solene da Congregação, tomou posse do cargo de Professor Catedrático de Direito Administrativo.

Em 30 de dezembro de 1937 renunciou ao cargo de ministro do Tribunal de Justiça do Estado, optando pelo de professor da Faculdade de Direito, e voltou ao exercício da advocacia.

Em 1945 foi eleito deputado federal, tomando parte nos trabalhos de elaboração da Constituição de 1946, como membro da Grande Comissão. Promulgada a Constituição a 18 de setembro de 1946, renunciour ao mandato no dia seguinte.

Em março de 1947, por indicação do Tribunal de Justiça, voltou ao cargo de desembargador desse Tribunal, com assento na $5^{a}$ Câmara Civil.

\section{BIBLIOGRAFIA}

a Projeto do Código do Processo — São Paulo, Tipografia Indiana, 1926.

O Conceito do Direito Administrativo - São Paulo, Escola Profissionais Salesianas, 1926.

Em face da Constituição Federal, não existe, no Brasil, o Contencioso Administrativo (Dissertação para concurso). São Paulo, Secção de Obras do Estado de São Paulo, 1927.

Natureza Juridica da Concessão de Serviço Público - (Dissertação para Concurso). São Paulo, Saraiva \& Cia., 1933.

Podem os municípios, no Estado de São Paulo, regulamentar o exercício de Profissôes? Revista da Faculdade de Direito, 1929. 
A célebre carta $C$ de D. Francisco Manuel de Melo - Revista da Faculdade de Direito, 1934.

Municipalização de serviços público: Revista da Faculdade de Direito, 1941.

Fundaçôes criadas por Testamento - Revista da Faculdade de Di reito, 1945.

Oração de Paraninfo - Revista da Faculdade de Direito, 1946. 